\title{
PENGEMBANGAN MODUL BERBASIS GUIDED DISCOVERY PADA MATERI SISTEM PERNAPASAN UNTUK MENINGKATKAN KEMAMPUAN BERPIKIR KRITIS SISWA KELAS XI SMA NEGERI 5 SURAKARTA
}

\author{
Nina Teja Suryani ${ }^{1}$, Baskoro Adi Prayitno ${ }^{2,}$,Yudi Rinanto ${ }^{3}$ \\ ${ }^{1}$ Magister Pendidikan Sains, Fakultas Keguruan dan Ilmu Pendidikan, Universitas Sebelas Maret \\ Surakarta, 57126, Indonesia \\ ninateja011@gmail.com \\ ${ }^{2}$ Magister Pendidikan Sains, Fakultas Keguruan dan Ilmu Pendidikan, Universitas Sebelas Maret \\ Surakarta, 57126, Indonesia \\ baskoro_ap@fkip.uns.ac.id \\ ${ }^{3}$ Magister Pendidikan Sains, Fakultas Keguruan dan Ilmu Pendidikan, Universitas Sebelas Maret \\ Surakarta, 57126, Indonesia \\ rinanto61@yahoo.co.id
}

\begin{abstract}
Abstrak
Penelitian ini bertujuan untuk: 1) mengembangkan modul dengan karakteristik guided discovery pada materi Sistem Pernapasan untuk meningkatkan kemampuan berpikir kritis siswa kelas XI SMA Negeri 5 Surakarta; 2) menguji kelayakan modul berbasis guided discovery pada materi Sistem Pernapasan untuk meningkatkan kemampuan berpikir kritis siswa kelas XI SMA Negeri 5 Surakarta; dan 3) menguji keefektivan modul berbasis guided discovery pada materi Sistem Pernapasan untuk meningkatkan kemampuan berpikir kritis siswa kelas XI SMA Negeri 5 Surakarta. Penelitian ini menggunakan metode Research and Development (R \& D) mengacu pada Borg dan Gall (1983) yang dimodifikasi menjadi sembilan tahapan yaitu: 1) penelitian dan pengumpulan informasi; 2) perencanaan; 3) pengembangan produk awal; 4) uji coba lapangan tahap awal; 5) revisi produk awal; 6) uji lapangan terbatas; 7) revisi produk kedua; 8) uji lapangan operasional yang menggunakan desain penelitian kuasi eksperimen; dan 9) revisi produk akhir. Analisis data yang digunakan adalah analisis deskriptif, teknik persentase dan uji Independent Samples T Test. Hasil penelitian menunjukkan: 1) karakteristik modul pada materi sistem pernapasan dikembangkan sesuai prosedur pengembangan Borg dan Gall yang dimodifikasi menjadi sembilan tahapan, dengan menggunakan sintaks model pembelajaran guided discovery yang bermuatan indikator-indikator kemampuan berpikir kritis yang divisualisasikan pada tujuan, materi, kegiatan, dan soal evaluasi modul; 2) kelayakan modul dinilai berkualifikasi sangat baik oleh penilaian ahli materi dengan pemenuhan 95,00\%; ahli pengembangan modul 93,26\%; ahli perangkat pembelajaran 90,57; dan ahli keterbacaan 96,88; rata-rata penilaian praktisi 98,29\%; serta rata-rata penilaian siswa $88,11 \%$; 3) Modul berbasis guided discovery efektif meningkatkan kemampuan berpikir kritis, didasarkan pada hasil uji Independent Samples T Test menunjukkan adanya perbedaan hasil post-test antara kelas yang menggunakan modul berbasis guided discovery dengan kelas yang menggunakan modul sekolah diperoleh sig $0,009<0,05$, serta peningkatan rata-rata $N$-gain sebesar 0,77 yang termasuk kualifikasi tinggi.
\end{abstract}

Kata kunci: modul, guided discovery, berpikir kritis, sistem pernapasan

\section{Pendahuluan}

Persaingan yang terjadi dalam era
globalisasi harus dihadapi dengan mempersiapkan sumber daya manusia yang berkualitas tinggi, yaitu sumber daya yang memiliki kemampuan dalam berpikir, bekerja, berkomunikasi serta penguasaan informasi dan teknologi untuk bekerja. Menurut pendapat Sadia (2008), kehidupan dalam era globalisasi dipenuhi oleh berbagai kompetisi-kompetisi yang sangat ketat. Keunggulan dalam berkompetisi terletak pada kemampuan dalam mencari dan menggunakan informasi, 
kemampuan analitis-kritis, keakuratan dalam pengambilan keputusan, dan tindakan yang proaktif dalam memanfaatkan peluang-peluang yang ada.

Kemampuan berpikir kritis merupakan salah satu tujuan yang paling penting dari semua sektor pendidikan (Phillips \& Bond, 2004: 277). Pentingnya kemampuan berpikir kritis juga diungkapkan oleh Bhisma (2012) yang menyatakan bahwa kemampuan berpikir kritis merupakan keterampilan penting untuk keberhasilan studi, bekerja dan hidup di era informasi dan teknologi abad ke-21 karena berpikir kritis memungkinkan memanfaatkan potensi dalam melihat masalah, memecahkan masalah, menciptakan dan menyadari diri. Pendapat tersebut diperkuat oleh Lipman dalam Redhana (2012: 3) yang menyatakan orang yang memiliki keterampilan berpikir kritis adalah orang yang mampu mengambil keputusan secara tepat, cepat, dan bertanggung jawab, dan mampu menghindarkan diri dari penipuan, indokrinasi, dan pencucian otak.

Penelitian Triwahyuni (2015) di Malang mengungkapkan pada siswa kelas $\mathrm{X}$ SMA Pawyatan Daha Malang data yang diperoleh pada siklus I adalah rata-rata nilai hasil tes evaluasi kemampuan berpikir kritis siswa sebesar 39,9 dan aktivitas belajar siswa sebesar $45 \%$ dari hasil pengamatan saat proses pembelajaran siswa masih kurang aktif dan terbiasa dengan metode ceramah. Penelitian yang dilakukan oleh Afrizon (2012) di Padang mengungkapkan rendahnya kemampuan berpikir kritis siswa kelas IX MTsN Model Padang berdasarkan hasil tes Eksplorasi Kemampuan Awal Siswa (EKAS). Penelitian Sadia (2008) juga menunjukkan bahwa keterampilan berpikir kritis siswa SMA kelas $\mathrm{X}$ di sembilan kabupaten yang ada di Bali, memiliki keterampilan berpikir kritis berkualifikasi rendah, dengan skor rata-rata 49,38 dan simpangan baku 16,92 (skor standar 100). Hasil observasi di SMA Negeri 5 Surakarta juga menunjukkan siswa kesulitan berpikir kritis. Hasil analisis yang dilakukan dengan memberikan tes kemampuan berpikir kritis berdasarkan pengembangan soal yang merujuk aspek-aspek kemampuan berpikir kritis yang diungkapkan Facione (2011) pada siswa kelas XI MIPA, diperoleh hasil sebagai berikut: 1) aspek interpretasi sebesar 58,47 kriteria cukup, 2) aspek analisis sebesar 58,18 kriteria cukup, 3) aspek evaluasi sebesar 61,67 kriteria cukup, 4) aspek kesimpulan sebesar 42,17 kriteria sangat kurang, 5) aspek penjelasan sebesar 44,23 kriteria sangat kurang, 6) aspek pengaturan diri sebesar 25,77 kriteria sangat kurang.

Analisis pemenuhan 8 Standar Nasional Pendidikan, khususnya pada standar proses menunjukkan adanya gap yang cukup tinggi yaitu sebesar 4,17 dari skor ideal. Adanya gap tersebut mengindikasikan masih terdapat kekurangan pada proses pembelajaran yang mengimbas pada perkembangan kemampuan berpikir kritis siswa.

Rendahnya standar proses dipengaruhi oleh kurang optimalnya proses pembelajaran yang berlangsung di kelas. Siswa kurang mengeksplorasi membangun pengetahuannya sendiri melalui pengalaman belajar, bahkan ketika diberi kesempatan untuk berdiskusi belum semua siswa mau berperan serta aktif. Hal tersebut memerlukan tindakan yang sesuai agar permasalahan yang ada dapat di atasi, salah satunya melalui perencanaan proses pembelajaran yang lebih baik.

Keberhasilan pembelajaran juga membutuhkan dukungan dari sarana prasarana yang erat kaitannya dengan ketersediaan sumber belajar. Menurut Toharudin (2011: 187) "Secara sederhana, sumber belajar dirumuskan sebagai segala sesuatu yang dapat memberi kemudahan kepada siswa dalam upaya memperoleh sejumlah informasi, pengetahuan, pengalaman dan keterampilan dalam proses belajar mengajar".

Modul merupakan salah satu bahan ajar yang memiliki peran strategis dan dapat dikembangkan sedemikian rupa sehingga dapat dipakai untuk melatihkan kemampuan berpikir kritis. Namun faktanya modul dan bahan ajar lain yang digunakan di sekolah belum dapat memberdayakan kemampuan berpikir kritis siswa.

Hasil analisis Ujian Nasional di SMA Negeri 5 menunjukkan persentase penguasaan materi Sistem Pernapasan masih di bawah KKM, yaitu pada tahun 2012/2013 adalah 
62,70, sedangkan pada tahun 2013/2014 adalah 53,24 (BSNP, 2014). Materi Sistem Pernapasan berhubungan dengan permasalahan kehidupan sehari-hari, namun banyak memiliki konsep-konsep yang abstrak. Oleh karena itu dalam pembelajarannya harus dimulai dari fakta-fakta terkait yang sering dihadapi oleh siswa. Dengan memperhatikan berbagai kondisi tersebut, maka model Guided Discovery merupakan salah satu model yang cocok untuk mengembangkan kemampuan berpikir kritis siswa. Menurut Veermans (2006) Guided Discovery merupakan suatu model pembelajaran yang berpusat pada siswa dan menekankan pada pemahaman diri yang dicapai melalui penyelidikan aktif. Model Guided Discovery lebih menekankan pada ditemukannya konsep atau prinsip yang sebelumnya tidak diketahui. Mengaplikasikan model Guided Discovery guru berperan sebagai pembimbing dengan memberikan kesempatan kepada siswa untuk belajar secara aktif, guru membimbing dan mengarahkan kegiatan belajar siswa sesuai dengan tujuan.

Kelebihan model Guided Discovery Learning yaitu dapat membantu siswa untuk memperbaiki dan meningkatkan keterampilan dan proses kognitif, pengetahuan yang diperoleh melalui model ini sangat pribadi dan menguatkan pengertian siswa serta dapat menimbulkan rasa senang pada siswa, karena tumbuhnya rasa menyelidiki dan berhasil menemukan konsep. Menurut Alfieri, dkk (2011), Guided Discovery akan membuat pembelajaran lebih bermakna, karena dalam pembelajaran siswa berupaya memahami informasi yang relevan, mengorganisasi informasi dan mengintegrasikan dengan pengetahuan yang sudah didapat. Menurut Syah (2004) sintaks Guided Discovery adalah Stimulation (pemberian rangsangan), Problem Statement (pernyataan/identifikasi masalah), Data Collection (pengumpulan data), Data Processing (Pengolahan data), Verification (pembuktian) dan Generalization (menarik kesimpulan/generalisasi). Melalui sintaks tersebut membuat siswa dapat memiliki pengalaman belajar yang menumbuhkan sikap ilmiah seperti rasa ingin tahu, tanggungjawab, berpikir kritis dan logis.
Materi Sistem Pernapasan yang disajikan dalam bentuk modul berbasis Guided Discovery diharapkan dapat mendorong siswa belajar melalui permasalahan praktis berdasarkan fakta dalam kehidupan sehari-hari, yang berhubungan dengan materi pelajaran sebagai suatu konteks bagi siswa untuk belajar tentang kemampuan berpikir kritis dalam memecahkan masalah, serta memperoleh pengetahuan dan konsep yang esensial dari materi pelajaran. Pembelajaran menggunakan modul memberikan kesempatan kepada siswa untuk meningkatkan aktivitas belajar secara optimal, sesuai dengan tingkat kemampuan dan kemajuan yang diperolehnya selama proses belajar. Menurut Prastowo (2011) pembelajaran dengan modul memungkinkan siswa memiliki kecepatan lebih tinggi dalam menyelesaikan kompetensi dasar.

Tujuan penelitian dan pengembangan ini adalah: 1) Mengembangkan modul dengan karakteristik guided discovery pada materi Sistem Pernapasan untuk meningkatkan kemampuan berpikir kritis siswa kelas XI SMA Negeri 5 Surakarta, 2) Menguji kelayakan modul berbasis guided discovery pada materi Sistem Pernapasan untuk meningkatkan kemampuan berpikir kritis siswa kelas XI SMA Negeri 5 Surakarta, 3) Menguji keefektivan modul berbasis guided discovery pada materi Sistem Pernapasan untuk meningkatkan kemampuan berpikir kritis siswa kelas XI SMA Negeri 5 Surakarta.

\section{Metode Penelitian}

Penelitian ini dilaksanakan di SMA Negeri 5 Surakarta kelas XI semester 2 Tahun Pelajaran 2015/2016. Jenis penelitian adalah penelitian dan pengembangan menggunakan metode Research and Development $(R \& D)$ mengacu pada Borg and Gall (1983) yang dimodifikasi menjadi sembilan tahapan yaitu: 1) penelitian dan pengumpulan informasi; 2) perencanaan; 3) pengembangan produk awal; 4) uji coba lapangan tahap awal; 5) revisi produk awal; 6) uji lapangan terbatas; 7) revisi produk kedua; 8) uji lapangan operasional yang menggunakan desain penelitian kuasi eksperimen; dan 9) revisi produk akhir. 
Data yang diperoleh dalam tahap penelitian dan pengumpulan data dianalisis secara kualitatif. Uji coba lapangan awal merupakan tahap proses validasi produk modul siswa dan modul guru oleh validator ahli meliputi; ahli materi modul, ahli pengembangan modul, ahli perangkat pembelajaran dan ahli keterbacaan. Pada tahap uji coba lapangan awal diperoleh hasil evaluasi deskriptif kualitatif untuk data pendapat dan saran serta deskriptif kuantitatif untuk skor penilaian. Uji lapangan terbatas dilakukan dengan validasi praktisi pendidikan (guru biologi) dan uji kelompok kecil (siswa). Subyek uji lapangan operasional adalah kelas XI MIPA1 dan kelas XI MIPA2 yang ditentukan melalui teknik cluster random sampling, desain penelitian pre-test and posttest nonequivalent control group design. Kelas XI MIPA1 menjadi kelas modul, proses pembelajaran pada kelas ini menggunakan modul berbasis guided discovery, sedangkan kelas XI MIPA2 menjadi kelas kontrol, yang dalam proses pembelajarannya menggunakan bahan ajar yang biasa digunakan di sekolah dan pembelajaran yang biasa dilakukan guru yaitu metode diskusi kelompok. Teknik analisis menggunakan Independent Samples $T$ Test dengan didahului dengan uji prasyaratnya yaitu uji homogenitas dan normalitas. Peningkatan kemampuan berpikir kritis siswa didasarkan pada perbandingan $\mathrm{N}$-gain.

\section{Hasil Penelitian dan Pembahasan}

\section{Karakteristik Modul Biologi Berbasis Guided Discovery untuk Meningkatkan Kemampuan Berpikir Kritis Siswa Kelas XI SMA Negeri 5 Surakarta.}

Pengembangan modul berbasis guided discovery pada materi sistem pernapasan sesuai dengan prosedur pengembangan Borg dan Gall (1983) yang dimodifikasi menjadi sembilan tahapan, dengan menggunakan sintaks model pembelajaran guided discovery, berdasarkan Kompetensi Dasar 3.8 yaitu menganalisis hubungan antara struktur jaringan penyusun organ pada sistem respirasi dan mengaitkannya dengan bioprosesnya sehingga dapat menjelaskan proses pernapasan serta gangguan fungsi yang mungkin terjadi pada sistem respirasi manusia melalui studi literatur, pengamatan, percobaan, dan simulasi, serta Kompetensi Dasar 4.8 yaitu menyajikan hasil analisis tentang kelainan pada struktur dan fungsi jaringan organ pernapasan/respirasi yang menyebabkan gangguan sistem respirasi manusia melalui berbagai bentuk media presentasi.

Modul berbasis guided discovery memberi kesempatan kepada seluruh siswa, baik yang memiliki kemampuan tingkat atas dan siswa yang memiliki kemampuan tingkat bawah, untuk bersama-sama membangun konsep dalam belajar, melalui sintaks pembelajaran yang menjadi basis pengembangan modul. Modul yang dikembangkan bertujuan melatihkan kemampuan berpikir kritis siswa dan dapat membawa dampak positif pada hasil belajarnya.

Aspek kemampuan berpikir kritis yang digunakan dalam pengembangan modul adalah interpretasi, analisis, evaluasi, kesimpulan, penjelasan, dan pengaturan diri (Facione, 2011). Aspek tersebut dilatihkan dalam aktivitas modul dan soal evaluasi. Aktivitas yang berbasis sintaks guided discovery dalam kegiatan diskusi, praktikum, dan presentasi yang diharapkan siswa mampu mengkonstruk konsep dan menyimpulkan materi yang diajarkan secara mandiri.

Karakteristik modul dengan basis model guided discovery diawali dengan pemberian stimulasi yang dapat memberikan stimulus kepada siswa tentang konsep awal terkait dengan pembelajaran yang akan dilakukan. Melalui stimulus yang diberikan siswa dapat melakukan interpretasi. Selanjutnya siswa mengidentifikasi masalah, dalam diri siswa akan muncul pertanyaanpertanyaan yang menimbulkan rasa ingin tahu, untuk menganalisis serta membuat hipotesis atas pertanyaan yang ada dan hipotesis yang disusun. Langkah selanjutnya mengumpulkan dan mengolah data, melalui kegiatan tersebut siswa dapat memperkuat kemampuan analisis dengan mengelola informasi melalui diskusi dan mencari referensi untuk melengkapi media yang akan disajikan dalam presentasinya. 
Selanjutnya menguji hasil yaitu siswa melakukan evaluasi dan pemeriksaan secara cermat untuk membuktikan benar atau tidaknya hipotesis yang ditetapkan sebelumnya dengan temuan alternatif, dihubungkan dengan hasil pengolahan data. Hasil dari seluruh kegiatan dan diskusi kelompok akan dipresentasikan, untuk memantau konsep yang telah diperoleh siswa, memperbaiki, serta menguatkan konsep yang telah dibangun selama diskusi. Melalui kegiatan presentasi siswa memberi penjelasan dan membuat kesimpulan untuk hal-hal yang penting berkaitan dengan konsep yang harus dikuasai.

Modul yang dikembangkan berupa modul siswa dan modul guru. Format pengembangan modul mengacu pada format isi modul menurut Mulyasa (2006) yaitu: 1) bagian pendahuluan; 2) tujuan pembelajaran; 3) pengalaman belajar; 4) sumber belajar; dan 5) tes akhir.

Secara sistematika isi modul lebih mengutamakan aktivitas siswa yang diberikan pada bagian depan modul, kemudian diikuti dengan uraian materi. Hal tersebut dimaksudkan agar siswa menjadi lebih aktif dan efektif dalam mengkonstruk pengetahuannya. Setiap sub pokok bahasan dibuat sistematis sesuai dengan aktivitas yang dilakukan siswa, mengacu pada indikator kompetensi yang harus dikuasai siswa. Pada akhir setiap sub pokok bahasan diberikan latihan soal terkait dengan aktivitas dan materi yang telah dipelajari sebelumnya, dengan tujuan untuk tolok ukur penguasaan materi oleh siswa, sedangkan soal evaluasi yang diberikan pada akhir materi secara keseluruhan bertujuan untuk tolok ukur tingkat penguasaan materi oleh siswa secara keseluruhan.

Modul guru memiliki format yang sama dengan modul siswa namun dilengkapi dengan suplemen yang meliputi pengantar untuk guru, rekomendasi skenario pembelajaran, konfirmasi aktivitas siswa dan instrumen penilaian.

\section{Kelayakan Modul Biologi Berbasis Guided Discovery untuk Meningkatkan Kemampuan Berpikir Kritis Siswa Kelas XI SMA Negeri 5 Surakarta.}

Hasil validasi ahli menunjukkan bahwa modul sudah sesuai tujuan yang dikembangkan. Berdasarkan penilaian ahli materi, modul telah mencapai persentase skor rata-rata $95,00 \%$, penilaian ahli pengembangan modul modul telah mencapai persentase skor rata-rata $93,26 \%$, penilaian ahli perangkat pembelajaran modul telah mencapai persentase skor rata-rata 90,57 dan penilaian ahli keterbacaan modul telah mencapai persentase skor rata-rata $96,88 \%$, sehingga secara keseluruhan modul memiliki kriteria kategori sangat baik, namun memerlukan beberapa perbaikan sesuai saran dari setiap ahli melalui revisi modul tahap awal.

Hasil revisi produk awal yang kemudian dilanjutkan uji lapangan terbatas yang melibatkan praktisi pendidikan dan siswa sebagai kelompok kecil. Hasil penilaian praktisi pendidikan dan siswa sebagai kelompok kecil pengguna menunjukkan bahwa modul hasil revisi produk awal telah sesuai dengan tujuan yang dikembangkan karena berkualifikasi sangat baik, dengan rincian menurut penilaian praktisi pendidikan modul telah mencapai persentase skor rata-rata 98,29\% dan penilaian siswa modul telah mencapai persentase skor rata-rata $88,11 \%$, namun masih memerlukan perbaikan sesuai saran yang diperoleh melalui revisi modul kedua.

Modul hasil revisi kedua kemudian diujikan melalui uji lapangan operasional/ keefektivan dan terbukti telah efektif dalam meningkatkan hasil belajar siswa, namun masih memerlukan perbaikan sesuai dengan saran beberapa siswa melalui revisi produk ketiga. Setelah melalui beberapa tahapan validasi ahli, penilaian praktisi pendidikan, uji lapangan operasional/uji keefektivan serta perbaikan-perbaikan yang telah dilakukan, maka hasil revisi produk ketiga (revisi produk akhir) merupakan produk jadi yang telah layak digunakan. 
3. Keefektivan Penggunaan Modul Biologi Berbasis Guided Discovery untuk Meningkatkan Kemampuan Berpikir Kritis Siswa Kelas XI SMA Negeri 5 Surakarta.

Uji lapangan operasional memperoleh data keterlaksanaan sintaks model pembelajaran, data nilai pre-test dan post test kemampuan berpikir kritis siswa, dan data pendukung berupa hasil belajar selama kegiatan proses pembelajaran berlangsung dan pada saat akhir pembelajaran.

Data keterlaksanaan sintaks model pembelajaran guided discovery oleh guru dan siswa disajikan pada Tabel 1 dan 2

Tabel 1 Keterlaksanaan Sintaks oleh Guru

\begin{tabular}{lcccc}
\hline \multirow{2}{*}{ Kegiatan Belajar } & \multicolumn{4}{c}{ \% Pertemuan } \\
\cline { 2 - 5 } & I & II & III & IV \\
\hline Stimulasi & 75,00 & 87,50 & 87,50 & 87,50 \\
\hline $\begin{array}{l}\text { Identifikasi } \\
\text { masalah }\end{array}$ & 81,25 & 81,25 & 93,75 & 93,75 \\
\hline $\begin{array}{l}\text { Mengumpulkan } \\
\text { data }\end{array}$ & 81,25 & 87,50 & 87,50 & 93,75 \\
\hline Mengolah data & 75,00 & 87,50 & 93,75 & 93,75 \\
\hline Verifikasi & 75,00 & 87,50 & 87,50 & 87,50 \\
\hline Menyimpulkan & 87,50 & 87,50 & 93,75 & 93,75 \\
\hline Rerata & 80,00 & 86,25 & 91,25 & 92,50 \\
\hline
\end{tabular}

Tabel 2 Keterlaksanaan Sintaks oleh Siswa

\begin{tabular}{lcccc}
\hline \multirow{2}{*}{ Kegiatan Belajar } & \multicolumn{4}{c}{ \% Pertemuan } \\
\cline { 2 - 5 } & I & II & III & IV \\
\hline Stimulasi & 75,00 & 75,00 & 87,50 & 87,50 \\
\hline $\begin{array}{l}\text { Identifikasi } \\
\text { masalah }\end{array}$ & 87,50 & 81,25 & 87,50 & 93,75 \\
\hline $\begin{array}{l}\text { Mengumpulkan } \\
\text { data }\end{array}$ & 81,25 & 87,50 & 93,75 & 93,75 \\
\hline Mengolah data & 81,25 & 87,50 & 87,50 & 93,75 \\
\hline Verifikasi & 75,00 & 87,50 & 87,50 & 87,50 \\
\hline Menyimpulkan & 75,00 & 87,50 & 93,75 & 93,75 \\
\hline Rerata & 80,00 & 85,00 & 90,00 & 92,50 \\
\hline
\end{tabular}

Analisis deskriptif statistik untuk data nilai pre-test dan post-test kemampuan berpikir kritis siswa kelas XI MIPA 1 (kelas modul) dan kelas XI MIPA 2 (kelas kontrol) disajikan pada Tabel 3.

Tabel 3 Deskriptif Statistik Nilai Pre-test dan Post-test Kelas XI MIPA1 dan XI MIPA 2

\begin{tabular}{llllll}
\hline \multirow{2}{*}{ Kelas } & Nilai & Range & $\begin{array}{c}\text { Nilai } \\
\text { Minim- } \\
\text { um }\end{array}$ & $\begin{array}{c}\text { Nilai } \\
\text { Maksi- } \\
\text { mum }\end{array}$ & Mean \\
\hline $\begin{array}{l}\text { Modul } \\
\text { (XI }\end{array}$ & $\begin{array}{l}\text { Pre- } \\
\text { MIPA 1) }\end{array}$ & 29.04 & 19.35 & 48.39 & 32.79 \\
\cline { 2 - 6 } & $\begin{array}{l}\text { Post- } \\
\text { test }\end{array}$ & 32.26 & 67.74 & 100.00 & 84.73 \\
\hline Kontrol & Pre- & & & & \\
\hline
\end{tabular}

\begin{tabular}{lccccc}
\hline \multirow{2}{*}{ Kelas } & Nilai & Range & $\begin{array}{c}\text { Nilai } \\
\text { Minim- } \\
\text { um }\end{array}$ & $\begin{array}{c}\text { Nilai } \\
\text { Maksi- } \\
\text { mum }\end{array}$ & Mean \\
\hline (XI & test & 38.71 & 19.35 & 58.06 & 35.05 \\
\cline { 2 - 6 } & $\begin{array}{l}\text { Post- } \\
\text { test }\end{array}$ & 35.48 & 61.29 & 96,77 & 79,35 \\
\hline
\end{tabular}

Berdasarkan tabel 3 data deskriptif statistik nilai pre-test kelas modul, perolehan nilai rata-rata sebesar 32,79 , nilai maksimum 48,39 dan nilai minimum 19,35, sehingga jarak antara nilai maksimum dan nilai minimum sebesar 29,04. Nilai pre-test kelas kontrol perolehan nilai rata-rata sebesar 35,05 maksimum 58,06 dan nilai minimum 19,35, sehingga jarak antara nilai maksimum dan minimum sebesar 38,71.

Deskriptif statistik nilai post-test perolehan kelas modul nilai rata-rata sebesar 84,73 , nilai maksimum 100,00 dan nilai minimum 67,74, sehingga jarak antara nilai maksimum dan nilai minimum sebesar 32,26. Nilai post-test kelas kontrol nilai rata-rata sebesar 79,35 dengan nilai maksimum 96,77 dan nilai minimum 61,29 sehingga jarak antara nilai maksimum dan minimum sebesar 35,48. Data-data tersebut menunjukkan nilai rata-rata kelas modul pada pre-test lebih rendah dibandingkan dengan nilai rata-rata kelas kontrol, namun setelah pembelajaran nilai ratarata kelas modul lebih tinggi dibandingkan dengan kelas kontrol.

Keefektivan modul berbasis guided discovery pada materi sistem pernapasan didasarkan pada hasil uji statistik yang menggunakan uji Independent Samples T Test dengan uji prasyarat yaitu uji normalitas dan homogenitas. Ringkasan uji normalitas dan homogenitas kemampuan berpikir kritis siswa disajikan pada Tabel 4.

Tabel 4 Ringkasan Uji Normalitas dan Homogenitas Kemampuan Berpikir Kritis

\begin{tabular}{|c|c|c|c|}
\hline Perlakuan & Uji & Jenis Uji & Hasil \\
\hline \multirow{2}{*}{$\begin{array}{l}\text { Modul } \\
\text { (Kelas XI } \\
\text { MIPA1) }\end{array}$} & \multirow[t]{2}{*}{$\begin{array}{l}\text { Normalit } \\
\text { as }\end{array}$} & \multirow{2}{*}{$\begin{array}{l}\text { Kolmogoro } \\
\text { v-Smirnov } \\
\text { test }\end{array}$} & $\begin{array}{l}\text { Sig pre-test }= \\
0,380\end{array}$ \\
\hline & & & $\begin{array}{l}\text { Sig post-test }= \\
0,122\end{array}$ \\
\hline \multirow{2}{*}{$\begin{array}{l}\text { Kontrol } \\
\text { (Kelas } \\
\text { MIPA2) }\end{array}$} & \multirow[t]{2}{*}{$\begin{array}{l}\text { Normalit } \\
\text { as }\end{array}$} & \multirow{2}{*}{$\begin{array}{l}\text { Kolmogoro } \\
\text { v-Smirnov } \\
\text { test }\end{array}$} & $\begin{array}{l}\text { Sig pre-test }= \\
0,697\end{array}$ \\
\hline & & & $\begin{array}{l}\text { Sig post-test }= \\
0,442\end{array}$ \\
\hline \multirow{2}{*}{$\begin{array}{lr}\text { Kelas } & \text { Modul } \\
\text { dan } & \text { kelas } \\
\text { kontrol } & \end{array}$} & \multirow[t]{2}{*}{$\begin{array}{l}\text { Homogen } \\
\text { itas }\end{array}$} & \multirow[t]{2}{*}{$\begin{array}{l}\text { Levene's } \\
\text { test }\end{array}$} & $\begin{array}{l}\text { Sig pre-test }= \\
0,342\end{array}$ \\
\hline & & & $\begin{array}{l}\text { Sig post-test }= \\
0,053\end{array}$ \\
\hline
\end{tabular}


Tabel 4 menunjukkan uji normalitas dengan jenis uji Kolmogorov-Smirnov pada nilai pretest dan post-test kemampuan berpikir kritis kelas modul diperoleh signifikansi sebesar 0,380 untuk nilai pre-test dan 0,122 untuk nilai post-test, sedangkan kelas kontrol diperoleh signifikansi sebesar 0,697 untuk nilai pre-test dan 0,442 untuk nilai post-test. Hasil uji normalitas nilai pre-test dan post-test menunjukkan signifikansi lebih besar dari $\alpha=$ 0,05 sehingga $\mathrm{H}_{0}$ diterima yang berarti nilai pre-test dan post-test kedua kelas tersebut terdistribusi normal. Uji homogenitas dengan jenis uji Levene's diperoleh signifikansi sebesar 0,342 untuk nilai pre-test dan 0,053 untuk nilai post-test, yang menunjukkan lebih besar dari $\alpha=0,05$, sehingga $\mathrm{H}_{0}$ diterima yang berarti variansi setiap sampel homogen. Uji prasyarat normalitas dan homogenitas terpenuhi, sehingga dapat dilanjutkan dengan uji parametrik Independent Samples T Test. Ringkasan hasil uji Independent Samples $T$ Test disajikan pada Tabel 5.

Tabel 5 Ringkasan Uji Analisis Statistik Kemampuan Berpikir Kritis

\begin{tabular}{lccc}
\hline \multicolumn{1}{c}{ Nilai } & Mean & $\begin{array}{c}\text { Std. } \\
\text { Deviation }\end{array}$ & Sig \\
\hline $\begin{array}{l}\text { Pre-test kelas } \\
\text { Modul }\end{array}$ & 32.79 & 6.287 & 0,286 \\
\hline $\begin{array}{l}\text { Pre-test kelas } \\
\text { Kontrol }\end{array}$ & 35.05 & 8.460 & \\
\hline $\begin{array}{l}\text { Post-test kelas } \\
\text { Modul }\end{array}$ & 84,73 & 8,593 & 0,009 \\
\hline $\begin{array}{l}\text { Post-test kelas } \\
\text { Kontrol }\end{array}$ & 79.35 & 6,808 & \\
\hline
\end{tabular}

Berdasarkan hasil uji yang tertera pada Tabel 5 untuk nilai pre-test diperoleh nilai signifikansi $0,286>0,05$ maka $\mathrm{H}_{0}$ diterima, yang berarti tidak ada perbedaan antara nilai pre-test kelas modul dan kelas kontrol, sedangkan untuk nilai post-test diperoleh nilai signifikansi $0,009<0,05$ maka $\mathrm{H}_{0}$ ditolak yang berarti ada perbedaan secara signifikan pada nilai post-test pada kelas modul dan kontrol.

Peningkatan kemampuan berpikir kritis siswa ditinjau berdasarkan perbandingan $N$-gain. Berdasarkan penghitungan yang dilakukan diperoleh hasil peningkatan rata-rata kemampuan berpikir kritis siswa setelah pembelajaran pada kelas modul lebih tinggi daripada kelas kontrol. Rata-rata peningkatan kelas modul sebesar 0,77 dengan kriteria tinggi, sedangkan pada kelas kontrol rata-rata peningkatan sebesar 0,68 dengan kriteria sedang, seperti yang disajikan dalam Tabel 6 .

Tabel 6 N-gain Nilai Kemampuan Berpikir Kritis Siswa Kelas Modul dan Kontrol

\begin{tabular}{cccc}
\hline Kelas & Minimum & Maksimum & $\begin{array}{c}\text { Rata- } \\
\text { rata }\end{array}$ \\
\hline Modul & 0,52 & 1,00 & 0,77 \\
Kontrol & 0,48 & 96,77 & 0,68 \\
\hline
\end{tabular}

Secara keseluruhan berdasarkan data hasil analisis yang telah dilakukan menunjukkan bahwa penggunaaan modul berbasis guided discovery pada materi sistem pernapasan lebih efektif dalam meningkatkan kemampuan berpikir kritis siswa. Hal tersebut sesuai dengan pernyataan Arjunan (2012), yang menyatakan bahwa pembelajaran yang melibatkan aktivitas guided discovery dapat menimbulkan ketertarikan siswa terhadap pelajaran, meningkatkan kemampuan mereka dalam mengajukan masalah dan meningkatkan kemampuan belajar dengan baik. Hal senada juga diungkapkan oleh Gholamian (2013), yang menyatakan bahwa guided discovery adalah suatu alat untuk mengembangkan dan memperkuat keterampilan pemikiran kritis. Guided discovery juga bermakna untuk pengajaran keterampilan pemikiran kritis dan banyak siswa yang memerlukan struktur awal langkah-langkah dalam pembelajaran yang menyediakan penghargaan dalam rangka membangun kepercayaan dan kemampuan siswa untuk berpikir kritis.

\section{Kesimpulan dan Rekomendasi}

Kesimpulan yang diperoleh dari penelitian pengembangan modul berbasis guided discovery pada materi sistem pernapasan adalah:

1. Karakteristik modul berbasis guided discovery pada sistem pernapasan dikembangkan sesuai prosedur pengembangan Borg dan Gall yang dimodifikasi menjadi sembilan tahapan, dengan menggunakan enam sintaks model pembelajaran guided discovery. 
2. Kelayakan modul berbasis guided discovery pada materi sistem pernapasan yang diuji melalui uji validasi ahli, uji kelompok kecil pengguna lapangan (praktisi pendidikan dan siswa) sudah sesuai dengan tujuan yang dikembangkan.

3. Modul berbasis guided discovery efektif dalam meningkatkan kemampuan berpikir kritis karena hasil uji statistik menunjukkan adanya perbedaan yang signifikan antara post-test kelas kontrol yang menggunakan modul biologi sekolah dengan kelas perlakuan yang menggunakan modul berbasis guided discovery pada materi sistem pernapasan.

Mengacu pada pelaksanaan dan hasil penelitian maka direkomendasikan:

1. Modul berbasis guided discovery pada materi sistem pernapasan layak digunakan oleh guru dan siswa sebagai alternatif bahan ajar yang mampu meningkatkan kemampuan berpikir kritis siswa.

2. Modul berbasis guided discovery perlu diimplementasikan dalam pembelajaran materi lain yang memiliki karakteristik yang sama dengan materi sistem pernapasan.

3. Modul berbasis guided discovery memerlukan uji penyebaran secara luas (disseminate) untuk menyempurnakan tahapan penelitian sesuai prosedur pengembangan Borg and Gall.

4. Uji keefektivan pada penggunaan modul guru berbasis guided discovery pada materi sistem pernapasan perlu dilakukan seperti pada keefektivan penggunaan modul siswa.

\section{Daftar Pustaka}

Afrizon, R. 2012. Peningkatan Perilaku Berkarakter dan Keterampilan Berpikir Kritis Siswa Kelas IX MTsN Model Padang pada Mata Pelajaran IPA-Fisika Menggunakan Model Problem Based Instruction. Jurnal Pembelajaran Fisika 1 UNP, 1-16.

Alfieri, L, Brook, P.J and Aldrich,N.J. 2011. Does Discovery-Based Instruction Enhance Learning?. Journal of Educational Psychology. Vol. 103, No. 1, 1-18
Arjunan, Jayachandran. Effects of Command and Guided Discovery Teaching Styles on Retention of a Psychomotor Skill. OSR Journal of Humanities and Social Science (JHSS) ISSN: 2279-0837, ISBN: 22790845. Volume 1, Issue 6 (Sep-Oct. 2012), 27-32.

Bhisma. 2012. Berpikir Kritis (Critical Thinking). Surakarta: Universitas Sebelas Maret.Online.http://fk.uns.ac.id/static/ materi/Berpikir_Kritis_Prof_Bhisma_Murt i.ppt. Diakses tanggal 14 Januari 2016

Borg and Gall. 1983. Education Research, An Introduction. New York \& London: Longman Inc. Choksy.

BSNP. 2014. Laporan Hasil Ujian Nasional Tahun Pelajaran 2013/2014. Software.

Facione, P.A. 2011. The Disposition Toward Critical Thinking. California: California Academic Press.

Gholamian, A. 2013. Studying the Effect of Guided Discovery Learning on Reinforcing the Creative Thinking of Sixth Grade Girl Students in Qom during 2012-2013 Academic Year pages 584-576 2013, Journal of Applied Science and Agriculture.

Mulyasa. 2006. Kurikulum Berbasis Kompetensi: Konsep, Karakteristik dan Implementasi. Bandung: Remaja Rosdakarya.

Phillips, V. \& Bond, C. 2004. "Undergraduates' Experiences of Critical Thinking." Higher Education Research \& Development, 23(3), 277-294.

Prastowo, A. 2012. Panduan Kreatif Membuat Bahan Ajar Inovatif. Jogja: DIVA Press.

Redhana, I Wayan. 2012. Model Pembelajaran Berbasis Masalah dan Pertanyaan Socratik untuk Meningkatkan Keterampilan Berpikir Kritis Siswa. Jurnal Cakrawala Pendidikan, November 2012, Th. XXXI, No. 3

Sadia, I Wayan. 2008. Model Pembelajaran yang Efektif untuk Meningkatkan Keterampilan Berpikir Kritis ( Suatu Persepsi Guru). Jurnal Pendidikan dan Pengajaran Undiksha. Diunduh tanggal 20 Agustus 2014 
JURNAL INKUIRI

ISSN: 2252-7893, Vol. 7, No. 1, 2018 (hal 101-110)

http://jurnal.uns.ac.id/inkuiri

Syah, M., 1996. Psikologi Pendidikan Suatu Pendekatan Baru. Bandung: PT Remaja Rosdakarya.

Toharudin, Uus, dkk. 2011. Membangun Literasi Sains Peserta Didik. Bandung. Humaniora.

Triwahyuni, dkk.2015 Application of Leraning Model PBL (Problem Based Learning) to Improve Critical Thinking Ability and Student Activities on Archaebacteria Eubacteria Topic in X Class Pawyatan Daha Senior High School. Malang: Prosiding Seminar Nasional Pendidikan Biologi 2015

Veermans, K. Wouter van Joolingen and Ton de Jong. 2007. Use of Heuristics to Facilitate Scientific Discovery Learning in a Simulation Learning Environment in a Physics Domain. International Journal of Science Education, 28, 341-361. 
JURNAL INKUIRI

ISSN: 2252-7893, Vol. 7, No. 1, 2018 (hal 101-110)

http://jurnal.uns.ac.id/inkuiri 